\title{
URGENSITAS MAHKAMAH KONSTITUSI MENGELUARKAN FATWA HUKUM DALAM PEMBENTUKAN UNDANG-UNDANG
}

\author{
Achmad Safiudin R., Jazim Hamidi, Tunggul Anshari, SN \\ Program Studi Magister Ilmu Hukum Fakultas Hukum Universitas Brawijaya \\ J1.MT.Haryono Nomor 169,Malang \\ Email: achmad.syafiuddin@gmail.comn
}

\begin{abstract}
Writing this scientific article discusses the urgency of the Mahkamaha Constitution to issue a legal fatwa in the formulation of laws. Based on the idea that the making of laws which constitute the rules of implementing the constitution, constitutional questions are not impossible to emerge at the time of the formation of laws by state legislatures, because the norms of constitutional material are abstract in nature. Therefore an alternative effort is needed, namely the submission of questions to the Constitutional Court regarding the norms of the articles of the Constitution, which relate to the laws to be made / form. Through these questions, a fatwa or legal consideration was issued from the Constitutional Court, so that the DPR and the President did not appear different interpretations in fulfilling the original intent of the constitution and meeting the constitutional rights of citizens. The writing of scientific articles uses empirical juridical research methods. The results of this scientific article are the legal fatwa of the Constitutional Court as the theoretical implications of the authority to examine the constitutionality of laws against the 1945 Constitution of the Republic of Indonesia can be based on a commitment to prevent acts of state administration which are not in accordance with the constitution as the highest state law. In addition, constitutional testing of the draft law through interpretation of the constitution constitutes control between state institutions (cheks and balances) to realize the ideals of a democratic legal state that prioritizes constitutional supremacy.
\end{abstract}

Keywords: Formation of Laws, Legal Considerations, Constitutional Interpretation.

\begin{abstract}
Abstrak: Penulisan artikel ilmiah ini membahas urgensi Mahkamaha Konstitusi mengeluarkan fatwa hukum dalam pembentukan undang-undang. Didasari pemikiran bahwa pembuatan undang-undang yang merupakan aturan pelaksana konstitusi, bukan tidak mungkin muncul pertanyaan-pertanyaan konstitusional pada saat pembentukan undang-undang oleh lembaga negara pembuat undangundang, dikarenakan norma materi-muatan konstitusi bersifar abstrak. Oleh karena itu perlu upaya alternatif pemikiran yaitu penyampaian pertanyaan ke Mahkamah Konstitusi terkait substansi norma pasal dari UUD, yang berkaitan dengan undang-undang yang akan dibuat/bentuk. Melalui pertanyaan tersebut maka keluarlah fatwa atau pertimbangan hukum dari Mahkamah Konstitusi, sehingga tidak muncul penafsiran berbeda oleh DPR dan Presiden dalam memenuhi original intent konstitusi dan memenui hak konstitusional warga negara. Penulisan artikel ilmiah ini menggunakan metode penelitian yuridis empiris. Hasil penulisan artikel ilmiah ini adalah fatwa hukum Mahkamah Konsitusi sebagai implikasi teoritis kewenangan menguji konstitusionalitas undang-undang terhadap UUD NRI Tahun 1945 dapat dilakukan didasarkan pada komitmen untuk mencegah tindakan-tindakan peyelenggaraan negara yang tidak sesuai dengan konstitusi sebagai hukum dasar tertinggi negara. Selain itu pengujian konstitusional rancangan undang-undang melalui penafsiran terhadap konstitusi merupakan kontrol antar lembaga negara (cheks and balances) untuk terwujudnya cita negara hukum yang demokratis yang mengedepankan supremasi konstitusi.
\end{abstract}

Kata Kunci: Pembentukan Undang-Undang, Pertimbangan Hukum, Penafsiran Konstitusi.

Kehadiran konstitusi merupakan conditio sine qua non (syarat mutlak) bagi sebuah negara. Konstitusi tidak saja memberikan gambaran dan penjelasan tentang mekanisme lembaga-lembaga negara, lebih dari itu di dalamnya ditemukan letak rasional dan kedudukan hak dan kewajiban warga 
negara. Konstitusi juga merupakan social contract (Hamid, 2000:34), antara yang diperintah (rakyat) dengan yang memerintah (penguasa, pemerintah). Begitu pentingnya kehadiran konstitusi di sebuah negara, krisis terhadap konstitusi menjadi masalah serius bagi sebuah negara demokratis (Soemantri, 1984:6).

Secara teoritis negara konstitusional, menuangkan pokok-pokok pandangan, pendirian, dan prinsip mengenai pengelolaan kehidupan bernegara di dalam sebuah konstitusi, baik tertulis (written constitution) maupun tidak tertulis (unwritten constitution) (Wheare, 1975:14-31). Pembahasan artikel ilmiah ini lebih difokuskan pada pengertian konstitusi sebagai Undang-Undang Dasar (grondwet).

Dalam penyusunan suatu konstitusi tertulis, norma Undang-Undang Dasar dipengaruhi oleh nilai-nilai yang hidup dalam masyarakat. Oleh karena itu, latar belakang filosofis, sosiologis, politis, dan historis perumusan yuridis suatu ketentuan Udang-Undang Dasar terdapat suasana kebatinan (geistichenhentergrund) yang perlu dipahami dengan seksama, untuk mengerti maksud dari ketentuan yang terdapat dalam pasal-pasal Undang-Undang Dasar dengan sebaik-baiknya (Asshiddiqie, 2014:29). Selain itu Undang-Undang Dasar (UUD) berkedudukan sebagai hukum dasar sebuah negara, sehingga menjadi referensi normatif bagi penyelenggaraan kehidupan berbangsa dan bernegara. Berisikan latar belakang hasrat bernegara, landasan filosofi kenegaraan, tujuan negara, struktur organisasi dan mekanisme pemerintahan negara (Thab, 2001:16-17). Ketentuan dasar konstitusi tertulis tersebut, berlaku juga dalam konstitusi negara Indonesia, yaitu UUD NRI Tahun 1945. Diyakini sebagai konstitusi normatif yang menjiwai dan mendasari gerak dan arah pembangunan nasional. UUD NRI Tahun 1945 merupakan konsep dasar sistem pengelolaan kehidupan nasional.

Seiring dengan perkembangan zaman, kerangka pemkiran (frame of reference) serta medan pengalaman (field of experience) terhadap konstitusi dapat berubah, sehingga proses pemahaman terhadap suatu ketentuan UndangUndang Dasar dapat terus berkembang dalam praktik kehidupan berbangsa dan bernegara. Oleh karena itu, penafsiran terhadap Undang-Undang Dasar pada masa lalu, masa kini, dan pada masa yang akan datang dapat terus digali dan dikomparasikan. Artinya konstitusi bukan barang sakral yang menolak penafsiran dari berbagai perspektif. Namun dengan syarat terdapan rujukan standar agar dapat dipertanggungjawabkan tidak menjadi alat kekuasaan sebuah rezim (Asshiddiqie, 2014.30). Semakin elastis suatu aturan, semakin terbuka kemungkinan untuk menampung dinamika perkembangan zaman, sehingga Undang-Undang Dasar tidak lekas ketinggalan zaman (verounderd). Haruslah disadari, meskipun perumusan Undang-Undang Dasar ini bersifat garis besar, jangan sampai ditafsirkan secara sewenang-wenang oleh pihak yang berkuasa karena ketentuan yang diatur bermakna ganda (Asshiddiqie, 2014.30).

Mengingat konstitusi sebagai hukum dasar yang tertinggi bersifat umum dan abstrak dan diperlukan aturan pelaksananya yaitu undangundang, maka pembentukan undang-undang membutuhkan penafsiran terhadap konstitusi. Dalam pembuatan undang-undang tidak menutup kemungkinan terdapat pertanyaan-pertanyaan konstitusional yang memerlukan sebuah jawaban. Adapun penafsiran yang selama ini dilakukan ialah dengan diputuskan sendiri oleh pembentuk undangundang. Praktik demikian menyimpan potensi terserabutnya substansi undang-undang dari substansi Undang-Undang Dasar, sehingga terdapat kasus tepat setelah disahkan sebuah undang-undang langsung diajukan judisial review ke Mahkamah Konstitusi karena dianggap bertentangan dengan Undang-Undang Dasar. Terdapat dua kemungkinan sebuah undang-undang saat diajukan judisial review di Mahkamah Konstitusi yakni dikabulkan atau ditolak. Menjadi persoalan ketika review undang-undang tersebut dikabulkan oleh Mahkamah Konstitusi, maka proses pembentukan yang sudah melalui proses yang cukup panjang dan lama, lalu kemudian langsung dibatalkan oleh Mahkamah Konstitusi, hal ini menandakan buruknya proses pembentukan sebuah undang-undang.

Sistem ketatanegaraan yang dibangun dan dijalankan harus seirama dengan ide dasar dan tujuan UUD NRI Tahun 1945. Menjadi persoalan serius apabila praktik penyelenggaraan ketatanegaraan tidak diikuti dengan proses pembentukan perundang-undangan yang baik, sebagai upaya mengiramakan dengan substansi UUD NRI Tahun 1945. Pembentukan undangundang di Indonesia saat ini dipandang belum berhasil memenuhi harapan masyarakat. Secara empiris, tergambar dari banyaknya permohonan 
uji materiil terhadap produk legislasi. Dari data MK, dalam Rekapitulasi Perkara Pengujian UndangUndang sejak tahun 2003, terdapat 898 kali uji materiil terhadap berbagai produk hukum berupa undang-undang.

Membludaknya permohonan uji materiil terhadap undang-undang sebagai produk legislasi di Mahkamah Konstitusi, diakibatkan kelemahan dalam meneliti dengan cermat draf-draf undangundang tersebut sesuai dengan konstitusi, atau kemungkinan adanya ambiguitas norma di dalam konstitusi yang menimbulkan multi tafsir, sehingga menyebabkan inkonsistensi-inkonsistensi terhadap undang-undang yang akan dibuat. Misalnya pada Pasal 18 ayat 4 dan Pasal 22E UUD NRI Tahun 1945 yang debatebel, serta pengaturan pemilihan kepala daerah bagian (rezim) dari pemilihan umum hanya diatur dalam Pasal 1 butir 4 UU No. 22 Tahun 2007. Perihal mengenai kewenangan MK dalam memutus sengketa pemilihan kepala daerah yang hanya diatur melalui UU No. 32 Tahun 2004 jo UU No. 12 Tahun 2008 tentang Pemerintahan Daerah khususnya Pasal 236C, patut untuk dipertanyakan konstitusionalitasnya (Mahfud, 2010:65 ).

Dari problematika yang telah dipaparkan di atas, perlu ada upaya alternatif pemikiran yaitu dengan menyampaikan pertanyaan ke Mahkamah Konstitusi terkait substansi norma pasal dari UUD, yang berkaitan dengan undang-undang yang akan dibuat/bentuk. Dengan pertanyaan tersebut dapat dikeluarkan fatwa atau pertimbangan hukum dari Mahkamah Konstitusi. Kajian terhadap urgensitas Mahkamah Konstitusi dalam mengeluarkan pendapat hukum yang berupa fatwa penting untuk dikaji lebih mendalam, sebagai upaya alternatif dalam menjaga konstitusionalitas undang-undang dan melindungi hak-hak konstitusional warga negara. Berdasarkan uraian diatas fokus kajian artikel ini adalah: 1. Problematika dalam pembentukan undang-undang, 2. Dampak terhadap konstitusionalitas dan hak konstitusioal warga negara, dan urgensi pengeluaran fatwa hukum oleh Mahkamah Konstitusi dalam pembentukan undang-undang.

\section{Metode}

Metode yang digunakan dalam penelisan artikel ini adalah metode penelitian hukum normatif, yakni suatu proses untuk menemukan aturan hukum, prinsip-prinsip hukum, maupun doktrin-doktrin hukum guna menjawab isu hukum yang dihadapi (Marzuki, 2010:35.). Pendekatan yang digunakan adalah pendekatan perundangundangan (statute approach), pendekatan konsep (conceptual approach), dan pendekatan kasus (case approach) (Ibrahim, 2012:301-302.).

\section{Pembahasan}

\section{Problematika dalam pembentukan Undang- Undang}

Pembentukan undang-undang yang menjadi kewenangan MPR bersama Presiden dinilai belum memberikan kontribusi siknifikan terhadap ekspektasi masyarakat akan terwujudnya undangundang yang konstitusional dan mampu menyerap aspirasi masyarakat. Hal ini dapat dilihat dari banyaknya undang-undang yang masuk dalam daftar uji di Mahkamah konstitusi. Sejak tahun 2003 terdapat 898 kali uji materiil terhadap undangundang di MK. Akumulasi data Mahkamah Konstitusi terdapat 230 permohonan uji materiil yang dikabulkan oleh MK, 344 ditolak dan 324 tidak diterima. Sehingga jika di prosentasekan maka dapat dikatakan 26\% undang-undang yang dikabulkan, 38\% undang-undang yang ditolak dan $36 \%$ undang-undang yang tidak diterima. Dengan konsekuensi ratusan pasal dan prosentase yang dibatalkan MK itu, menandakan belum baiknya pembuatan undang-undang selama ini. Jika kualitasnya baik, tidak mungkin MK membatalkan sampai 230 kali.

Fenomena ketatanegaraan berupa lahirnya beberapa undang-undang yang setelah diundangkan tidak lama kemudian diajukan judicial review ke Mahkmah Konstitusi dan juga adanya undang-undang yang lahir tanpa pengesahan Presiden, menjadi suatu indikasi bahwa dalam pembentukan undang-undang selama ini terdapat resistensi kepentingan politik antara DPR dengan Presiden yang dapat mengesampingkan amanat UUD NRI Tahun 1945. Fenomena tersebut salah satunya dapat dijelaskan dalam UU dibawah ini:

\section{UU No. 32 Tahun 2002 tentang Penyiaran}

Regulasi terkait dengan penyiaran memang pada kenyataanya sangat pelik dalam proses perumusannya. Terbukti, selalu ada beragam kepentingan yang harus diakomodir sehingga 
muncul indikasi bahwa substansi UU Penyiaran merupakan deal antara penguasa dengan kalangan bisnis pertelevisian sekaligus menjadi alat kepentingan politik pemerintah. RUU tentang Penyiaran Tahun 2000 diusulkan oleh 26 (dua puluh enam) anggota DPR sebagai usul perubahan atas UU No. 24 Tahun 1997 tentang Penyiaran. Para pengusul mengemukakan penjelasannya di depan Rapat Paripurna DPR tanggal 21 Juli 2000 dengan menjabarkan latar belakang diajukannya RUU inisiatif DPR tersebut. Di antaranya, UU No. 24 Tahun 1997 merefleksikan kehendak rezim penguasa untuk melakukan kontrol politik terhadap media elektronik, tanpa menghiraukan kepentingan publik bahkan lebih merupakan pengekangan dan pengingkaran terhadap demokrasi dan HAM. Pengingkaran terhadap demokrasi ini ditemukan dalam filosofi UU No. 24 Tahun 1997 yang menyatakan bahwa "...penyiaran dikuasai negara...". konsekuensi utamanya, distribusi spektrum gelombang elektromagnetik yang dinyatakan dikuasai oleh negara yang pelaksanaanya oleh Departemen Perhubungan menjadi tidak transparan (Laksono dan Subardjo, 2006:116-117).

Atas dasar itu menurut para pengusul, diperlukan suatu undang-undang tentang penyiaran yang performatif dan mampu menjamin serta memenuhi tuntutan kebutuhan akan hak kemerdekaan informasi yang demokratis. RUU yang diajukan para pengusul ditanggapi positif oleh fraksi-fraksi di DPR dalam Rapat Paripurna Terbuka DPR tanggal 4 Juli 2000. Seluruh fraksi menyetujui RUU usul inisiatif anggota tentang Penyriaran ini untuk diteruskan dan dibahas lebih lanjut dalam tingkat pembicaraan berikutnya guna menjadi RUU usul inisiatif DPR. Namun melihat pertarungan politik yang terjadi sebenarnya, terlihat bahwa rumusan-rumusan yang dimunculkan baik oleh Pemerintah maupun oleh DPR mengandung spirit hendak kembali ke sistem media otoritarian. Dalam RUU tersebut paradigma otoritarian belum ditinggalkan terutama temaktub dalam pasal-pasal yang mengatur pembatasan pemusatan kepemilikan media penyiaran dan kepemilikan silang, pelembagaan penyiaran publik dan komunitas, serta penentuan KPI sebagai lembaga regulasi penyaran independen (Laksono dan Subardjo, 2006:119)..

Persoalan otoritas pengaturan penyiaran yang tetap berada ditangan pemerintah tidak dikehendaki oleh masyarakat penyiaran dan para aktivis demokrasi. Dalam draft RUU Penyiaran, DPR justru kemudian memberikan kekuasaan kepada pemerintah untuk mengatur, mengintervensi dan mengontrol penyiaran. Kekuasaan pemerintah untuk mengatur penyiaran ini secara halus "dialihkan" ke KPI. Dalam kewenangan pemberian izin frekwensi, KPI hanya sebagai pengusul (counselor body) dan delivery man (Laksono dan Subardjo, 2006:116-117).

Melihat realitas yang ada, secara substansial RUU Penyiaran tidak pernah terlepas dari beragam interest, baik itu oleh pengusaha pers, Pemerintah maupun DPR. Pemerintah memiliki kepentingan tendensi bisnis sementara DPR memiliki kepentingan menyuarakan aspirasi rakyat yang seringakali berbeda dengan pemerintah. RUU Penyiaran itu lahir di tengah perang kepentingan antar elemen masyarakat penyiaran, yang beralih menjadi perang gagasan antara DPR versus Pemerintah. Perbedaan pandangan itu disikapi dengan begitu hati-hati oleh Presiden Megawati. Perbedaan pendapat ini menuntun Megawati melakukan tindakan tidak populis yakni dengan tidak menandatanganinya UU No. 32 Tahun 2002 tentang Penyiaran tersebut (Laksono dan Subardjo, 2006:116-117).

Ikatan Jurnalis Televisi Indonesia, Persatuan Radio Swasta Nasional Indonesia (PRSNI), Persatuan Perusahaan Periklanan Indonesia (PPPI), Asosiasi Televisi Siaran Indonesia, Persatuan Sulih Suara di Indonesia (Persusi), dan Komunitas Televisi Indonesia tidak lama setelah itu mengajukan judicial review ke Mahkamah Konstitusi dan kemudian Mahkamah Konstitusi mengeluarkan Putusan Nomor 005/PUU-I/2003 yang isinya mengabulkan sebagian tuntutannya (Laksono dan Subardjo, 2006:127).

UU No. 22 Tahun 2014 sebagaimana telah diubah UU 1 Tahun 2015 sebagaimana telah diubah UU 8 Tahun 2015 tentang Pemilihan Gubernur, Bupati, dan Walikota

Polemik yang muncul diawali dari disahkannya UU Nomor 22 tahun 2014 tentang Pilkada oleh DPR periode 2009-2014 yang pemilihan kepala daerah melalui DPRD. Pengesahan UU tersebut langsung menjadi perhatian publik dan memunculkan pro dan kontra di masyarakat. Kemudian Presiden SBY saat itu mengeluarkan Peraturan Pemerintah Pengganti Undang-undang (Perppu) yang mengembalikan 
Pilkada langsung. Meskipun akhirnya Perppu tersebut kemudian diterima DPR menjadi UU, tetapi seluruh fraksi menghendaki untuk direvisi secara terbatas hingga sampai pembentukan UU 8 Tahun 2015 tentang Pemilihan Gubernur, Bupati, dan Walikota.

Eksistensi UU 8/2015 menjadi dipertanyakan ketika muncul fenomena 25 judicial review dan 7 diantaranya dikabulkan. Evaluasi yang dapat dipetik dari kenyataan ini bahwa UU 8/2015 adalah jauh dari sempurna, hal ini dikarenakan UU ini hadir dari hasil Perppu yang tentu saja tidak dibentuk dalam waktu singkat oleh pihak Pemerintah. Dikarenakan pada tahun 2015 ini banyak kepala daerah yang menginjak akhir masa jabatannya, sejak awal revisi UU 1/2015 hanya melakukan perubahan seperlunya saja. Namun ketika didalami ternyata UU 1/2015 tersebut benar-benar dibuat secara terburu-buru sehingga jika melihat banyaknya judicial review ke MK dapat disimpulkan bahwa UU 8/2015 belum berhasil menyempurnakan hasil karya Perppu tersebut. Sehingga kedepan ada baiknya UU Pilkada perlu untuk revisi kembali bahkan selayaknya dicabut dan diganti yang baru, karena sejak awal pun UU 1/2015 telah mengalami perubahan lebih dari 50\% pada UU 8/2015 (Rajab, 2016:362).

UU 8/2015 dan Undang-Undang Nomor 1 Tahun 2015 tentang Penetapan Peraturan Pemerintah Pengganti Undang-Undang Nomor 1 Tahun 2014 Tentang Pemilihan Gubernur, Bupati, Dan Walikota Menjadi Undang-Undang (UU 1/2015), keduanya adalah UU Pilkada yang dijadikan sebagai dasar hukum pelaksanaan Pilkada serentak pada tanggal 9 Desember 2015. UU 8/2015 ini merupakan perubahan dari UU 1/2015 yang lahir dari Peraturan Pemerintah Pengganti Undang-Undang Nomor 1 Tahun 2014 tentang Pemilihan Gubernur, Bupati, dan Walikota (Perppu 1/2014). Adapun Perppu 1/2014 ini lahir seminggu setelah pada Paripurna tanggal 26 September 2014 disetujui bersama UU Pilkada yang mengatur pemilihan secara tidak langsung yakni Undang-Undang Nomor 22 Tahun 2014 tentang Pemilihan Gubernur, Bupati, dan Walikota (UU 22/ 2014). Dinamika politik yang terjadi antara pembentukan UU 22/2014, UU 1/2015, hingga UU 8/2015 membawa banyak sekali permasalahan.

Hal tersebut berawal dari Pemerintah mengajukan 3 RUU yang merupakan pecahan dari UU nomor 32 tahun 2004. Ketiga RUU tersebut adalah RUU tentang Desa, RUU Pemda dan RUU Pilkada. RUU tentang Desa telah disahkan menjadi UU nomor 6 tahun 2014. Sementara untuk
RUU Pemda dan RUU Pilkada pembahasannya sangat alot. Ada pro dan kontra terkait pelaksanaan pemilihan kepada daerah. Mayoritas fraksi di DPR menghendaki agar pemilihan kepala daerah dilakukan melalui DPRD alias tidak langsung. Sementara ada dorongan kuat dari publik agar Pilkada tetap digelar secara langsung. Pemerintah pun didesak menarik diri dari pembahasan RUU Pilkada.

Pada 25 September 2014 DPR menggelar rapat paripurna pengesahan RUU Pilkada. Rapat berlangsung alot karena banyak pasal yang belum disepakati. Dua kubu pasangan calon presiden dan wakil presiden yakni Koalisi Indonesia Hebat dan Koalisi Merah Putih. Koalisi Indonesia Hebat yang mengusung Joko Widodo-Jusuf Kalla mendukung Pilkada langsung. Sebaliknya Koalisi Merah Putih pengusung Prabowo Subianto-Hatta Rajasa mendukung Pilkada tak langsung. Dan pada akhirnya sidang paripurna pembahasan tingkat II Rancangan Undang-undang Pemilihan Kepala Daerah (RUU Pilkada) di DPR telah rampung. Proses panjang ini akhirnya berakhir dengan diterimanya RUU Pilkada yang memuat ketentuan pelaksanaan pilkada melalui DPRD. Dengan begitu, DPRD lah yang nantinya memilih kepala daerah. Bukan lagi rakyat, seperti yang sudah berlangsung beberapa waktu terakhir ini. Pemungutan suara menghasilkan jarak suara yang sangat jauh, yaitu 135 suara untuk yang memilih pilkada langsung dan 226 suara untuk yang memilih pilkada melalui DPRD dari 361 anggota DPR yang bertahan dalam rapat paripurna.

Pemilihan Kepala Daerah dan Wakil Kepala Daerah atau Pemilihan Gubernur, Bupati, dan Walikota adalah perintah atributif dalam Pasal 18 ayat (4) UUD NRI Tahun 1945 yang menyatakan "Gubemur, Bupati, dan Walikota masingmasing sebagai kepala pemerintah daerah provinsi, kabupaten, dan kota dipilih secara demokratis". Adapun politik pemilihan Gubernur, Bupati, dan Walikota dalam hal memaknai frase "dipilih secara demokratis" selalu mengalami perubahan sesuai dengan perkembangan zaman. Hal inilah yang kemudian menjadi dasar bahwa terdapat perubahan metode pemilihan Gubernur, Bupati, dan Walikota yang dapat dilaksanakan baik itu secara langsung maupun tidak langsung. Pengaturan terkait pemilihan ini pun diatur dalam sejumlah UU mulai dari pengaturan dalam UU Pemerintahan Daerah yakni Undang Undang Nomor 22 Tahun 1999 (UU 22/1999) dan 
perubahannya Undang-Undang Nomor 32 Tahun 2004 (UU 32/2004), hingga pengaturan tersendiri dalam UU tersendiri mulai dari UU 22/2014 hingga yang terakhir yakni UU $1 / 2015$ dengan perubahannya UU 8/2015 (Rajab, 2016:349).

MK menyatakan bahwa pemilihan kepala daerah bukanlah rezim Pemilu, hal ini dimulai semenjak terbitnya Putusan Mahkamah Konstitusi No. 97/PUU-XI/2013. Dalam Putusan tersebut pemilihan umum hanyalah diartikan hanyalah limitatif sesuai dengan original intent menurut Pasal 22E UUD NRI Tahun 1945, yaitu Pemilihan Umum yang diselenggarakan untuk memilih anggota DPR, DPD, Presiden dan Wakil Presiden serta DPRD dan dilaksanakan setiap 5 tahun sekali. Sehingga perluasan makna Pemilu yang mencakup Pemilihan Gubernur, Bupati, dan Walikota (Pemilihan Kepala Daerah dan Wakil Kepala Daerah) adalah inkonstitusional menurut Mahakamah Konstitusi (Putusan Mahkamah Konstitusi Nomor 97/PUU-XI/2013). Dikarenakan pemilihan kepala daerah bukanlah rezim Pemilu melainkan rezim Pemerintahan Daerah (Pemda) maka istilah yang paling mungkin adalah digunakan adalah "Pemilihan" atau setidaktidaknya menggunakan istilah Pilkada (Pemilihan Kepala Daerah) bukan Pemilihan Umum (Pemilu) Kepala Daerah (Rajab, 2016:350).

Pilkada adalah perintah atributif dalam Pasal 18 ayat (4) UUD NRI Tahun 1945 yang menyatakan "Gubemur, Bupati, dan Walikota masing-masing sebagai kepala pemerintah daerah provinsi, kabupaten, dan kota dipilih secara demokratis" dalam perkembangannya seringkali perubahan. Ketika terbit Putusan Mahkamah Konstitusi No. 072-073/PUU-II/2004, Pilkada digolongkan masuk dalam rezim Pemilu. Sedangkan ketika terbit Putusan MK No. 97/PUU$\mathrm{XI} / 2013$, Pilkada digolongkan sebagai rezim Pemda (bukan rezim Pemilu). Adapun terkait pelaksanaan apakah langsung atau tidak pada hakikatnya MK tidaklah membatasi apakah harus langsung begitu juga sebaliknya, namun yang pasti MK menyatakan bahwa baik kedua metode tersebut, keduanya adalah sama-sama demokratis (Rajab, 2016:361).

\section{UU No. 42 Tahun 2008 tentang Pemilihan Umum Presiden dan Wakil Presiden}

Pembentukan UU No. 42 tahun 2008 tentang Pilpres tidak lepas juga dari proses perdebatan yang membuat banyak kalangan tidak setuju, ada beberapa pasal-pasalnya yang menjadi salah satu faktor penghambat bagi lahirnya capres alternatif dalam pemilu, apalagi proses seleksi calon presiden yang dilakukan oleh institusi partai politik tidak transparan dan cenderung mengakomodir kepentingan penguasa partai dan elit-elit parpol saja. Padahal, terdapat begitu banyak figur alternatif pemimpin nasional dari berbagai latar belakang, baik kader parpol maupun di luar parpol yang bisa di munculkan dimana rakyat tidak diberikan kesempatan dalam memilih figur pemimpin nasional berdasarkan espektasinya (Aryani, 2017).

Menjadi calon Presiden dan Wakil Presiden harus memenuhi persyaratan-persyaratan tertentu yang diatur dalam Undang-Undang Nomor 42 Tahun 2008. Calon Presiden tidak hanya diusulkan oleh partai politik atau gabungan partai politik, juga partai politik atau gabungan partai politik harus memenuhi ambang batas (presidential threshold) yaitu partai politik atau gabungan partai politik harus memenuhi perolehan kursi paling sedikit $20 \%$ (dua puluh persen) dari jumlah kursi di DPR atau memperoleh $25 \%$ (dua puluh lima persen) dari suara sah nasional dalam pemilu anggota DPR. Dengan demikian, dengan mengkaji permohonan uji materi Undang-Undang Nomor 42 Tahun 2008 terhadap UUD 1945 yang diajukan oleh Yusril Ihza Mahendra, yaitu tidak hanya pemilu serentak antara pemilu legislatif dengan pemilu presiden dan wakil presiden saja, tetapi juga mengenai peniadaan atau dihapuskannya ambang batas (presidential threshold) dalam pemilu presiden dan wakil presiden (Sodikin, 2014:10).

Syarat ambang batas pengajuan calon presiden atau presidential threshold (PT) yang diatur dalam Undang-Undang Nomor 42 Tahun 2008 tentang Pemilihan Presiden tidak didasari argumentasi yang tepat. Penerapan PT untuk mengusung pasangan calon presiden dan wakil presiden dianggapnya sebagai permainan politik partai-partai besar, penerapan PT dalam UndangUndang Pilpres tidak masuk akal, karena UUD 1945 telah mengatur bahwa presiden terpilih berdasarkan perolehan suara $50 \%$ plus satu dan tersebar di $20 \%$ provinsi. Selanjutnya, pernyataan yang menyatakan bahwa penerapan PT dilakukan untuk memperkuat sistem presidensial juga tidak bisa dibuktikan. Apabila Presiden yang terpilih berasal dari partai kecil, pembentukan kabinet juga pasti akan dilakukan secara koalisi. Contoh lainnya 
adalah Partai Demokrat dengan suara minoritas pada tahun 2009 akhirnya mengajak partai Golkar masuk dalam kabinet meski dalam pemilihan presiden harus berkompetisi (Sodikin, 2014:11).

Permohonan uji materi Undang-Undang Nomor 42 Tahun 2008 terhadap UUD 1945 yang diajukan oleh Yusril Ihza Mahendra sebagaimana dalam Putusan Mahkamah Konstitusi Nomor 108/ PUU-XI/2013 adalah pada intiya sebagai berikut:

Bahwa Mahkamah Konstitusi, yang berdasarkan kewenangan yang diberikan oleh Undang-Undang Dasar untuk menguji Undang-Undang terhadap Undang-Undang Dasar, dalam berbagai pertimbangan hukum putusannya ternyata telah menyebut dirinya sebagai "the sole interpreter of the constitution" atau "penafsir tunggal konstitusi". Terkait dengan permohonan ini, maka Pemohon memohon sudilah kiranya Mahkamah menafsirkan apakah sesungguhnya maksud teks norma dalam Pasal 6A ayat (2), Pasal 22E ayat (1), (2) dan (3) dikaitkan dengan sistem pemerintahan presidensial sebagaimana diatur oleh norma Pasal 4 ayat (1) dan Pasal 7C Undang-Undang Dasar 1945; Pemohon adalah persorangan warga negara Indonesia yang memiliki hak-hak konstitusional, yang diberikan oleh Pasal 6 ayat (1) UUD 1945 yakni hak untuk dicalonkan sebagai calon Presiden Republik Indonesia, yang selanjutnya pelaksanaan hak konstitusional tersebut diatur dalam Pasal 6A ayat (2), Pasal 7C, Pasal 22E ayat (1), ayat (2), dan ayat (3) UUD 1945. Hak-hak konstitusional tersebut tata cara pelaksanaannya nyatanyata telah dirugikan dengan berlakunya norma Undang-Undang sebagaimana diatur dalam Pasal 3 ayat (5), Pasal 9, Pasal 14 ayat (2) dan Pasal 112 UndangUndang Nomor 42 Tahun 2008 tentang Pemilihan Umum Presiden dan Wakil Presiden;

Penafsiran oleh Mahkamah Konstitusi atas norma Pasal 6A ayat (2), Pasal 22E ayat (1), ayat (2) dan ayat (3) tentang pemilihan Presiden dan Wakil Presiden dikaitkan dengan sistem pemerintahan Presidensial sebagaimana diatur oleh norma Pasal 4 ayat (1) dan Pasal 7C
UUD 1945 diharapkan akan menghasilkan tafsir yang otoritatif dari para hakim yang merupakan "negarawan yang memahami konstitusi" bukan tafsir para legislator di DPR dan Presiden yang terkadang bias dalam menafsirkan norma konstitusi ke dalam Undang-Undang karena berbagai kepentingan politik yang melatarbelakanginya.

Adapun jawaban pertimbagan hukum Mahkamah Konstitusi dalam putusan yakni: (Sodikin, 2014:21).

Mahkamah adalah pelaku kekuasaan kehakiman sebagaimana dimaksud dalam Pasal 24 ayat (1) dan ayat (2) UUD 1945 yang menyatakan, "Kekuasaan Kehakiman merupakan kekuasaan yang merdeka untuk menyelenggarakan peradilan guna menegakkan hukum dan keadilan" dan "Kekuasaan kehakiman dilakukan oleh sebuah Mahkamah Agung dan badan peradilan yang berada di bawahnya dalam lingkungan peradilan umum, lingkungan peradilan agama, lingkungan peradilan militer, lingkungan peradilan tata usaha negara, dan oleh sebuah Mahkamah Konstitusi." Oleh karena itu, penafsiran Mahkamah terhadap UUD 1945 dengan demikian adalah penafsiran dalam rangka penegakan hukum dan keadilan untuk menyelesaikan kasus konstitusional yaitu penafsiran konstitusionalitas pasal atau norma Undang-Undang terhadap UUD 1945 yang menjadi kewenangan Mahkamah sebagaimana dimaksud dalam Pasal 24C ayat (1) dan ayat (2) UUD 1945. Selain itu, penafsiran yang dimohonkan Pemohon dapat dikategorikan sebagai permohonan untuk mengeluarkan fatwa kepada Mahkamah melalui penafsiran terhadap pasal UUD 1945. Berdasarkan pertimbangan tersebut di atas petitum permohonan angka 3 dan angka 4 , menurut Mahkamah, tidak menjadi kewenangan Mahkamah.

Berangkat dari problematika di atas, maka sesungguhnya indikator-indikator secara teoritis hukum di dalam penciptaan suatu norma merupakan aspek yang wajib untuk dicermati oleh 
para pembentuk undang-undang, termasuk dalam hal menentukan ambang batas formal. Mahkamah Konstitusi sendiri di dalam putusannya menyadari bahwa perancangan perundangan-undangan pemilihan umum seakan tidak memiliki konsep yang jelas perihal bagaimana desain pemilihan umum Indonesia yang demokratis, sehingga kenyataan hukum yang terjadi adalah berkembanganya paradigma kebiasaan melakukan perubahan maupun pergantian undang-undang pemilu menjelang penyelenggaraannya (Putusan Mahkamah Konstitusi No. 3/PUU-VII/2009, hal 130-131).

Dalam teori materi muatan konstitusi bahwa suatu konstitusi berisi 3 (tiga) hal pokok, yaitu: (i). Adanya jaminan terhadap hak-hak asasi manusia dan warga negaranya, (ii). Ditetapkannya susunan ketatanegaraan suatu negara yang bersifat fundamental, (iii). Adanya pembagian dan pembatasan tugas ketatanegaraan yang bersifat fundamental. Fungsi esensial konstitusi dalam arti material adalah menentukan lembaga-lembaga dan prosedur pembentukan undang-undang dan juga sampai derajat materi-muatan peraturan yang akan dibentuk. Dengan demikian muncul problem bagaimana menjamin kepatuhan terhadap ketentuan-ketentuan konstitusi, bagaimana melindungi konstitusionalitas peraturan perundangundangan yang dapat diindikasi melanggar hak fundamental yang dijamin oleh konstitusi karena abstraksinya yang butuh penafsiran seperti beberapa kasus yang telah diuraikan di atas. Ini suatu kasus problem umum mengenai jaminan bahwa norma hukum yang lebih yang rendah sesuai dengan norma hukum yang lebih tinggi yang menentukan adalah materi-muatannya.

\section{Dampak terhadap Konsttitusionalitas dan Hak-Hak Konstitusional Warga Negara}

Konstitusionalitas berarti mempertanyakan perihal atau keadaan validitas konstitusional undang-undang. Pengujian konstitusionalitas undang-undang membutuhkan penafsiran konstitusi dengan fokus pada norma dan/atau pembentukan suatu undang-undang bertentangan atau tidak dengan konstitusi. Pengujian konstitusional memiliki dua tugas pokok yaitu pertama, untuk menjamin berfungsinya sistem demokrasi dalam hubungan perimbangan peran antara cabang-cabang kekuasaan legislatif, eksekutif, dan yudikatif. Dalam hal ini pengujian konstitusional dimaksudkan untuk mencegah terjadinya penggunaan kekuasaan oleh salah satu cabang kekuasaan negara dengan mengorbankan cabang kekuasaan negara lainnya; kedua, untuk melindungi setiap individu warga negara dari penyalahgunaan kekuasaan oleh lembaga-lembaga negara sehingga merugikan hak-hak fundamental individu-individu tersebut yang dijamin oleh konstitusi (Asshiddiqie, 2005:10-41). Keberadaan norma atau ketentuan tentang perlindungan hakhak konstitusional di dalam konsitutsi memiliki pengaruh hukum signifikan, dengan adanya pembatasan terhadap kekuasaan negara atau untuk menciptakan "pemerintahan yang terbatas", suatu sistem pemerintahan dimana kekuasaan absolut tidak diberikan kepada organ negara manapun (Palguna, 2013:137). Hak konstitusional adalah hak dasar warga negara yang dijamin oleh konstitusi. Hak dasar menjadi bagian tidak terpisahkan dari materi dari konstitusi. Menurut Mr. J. G. Steenbeek mengungkapkan bahwa secara umum konstitusi memuat tiga hal pokok, yaitu: adanya jaminan terhadap hak-hak asasi manusia dan warga negaranya, ditetapkannya susunan ketatanegaraan suatu negara yang bersifat fundamental, adanya pembagian dan pembatasan tugas ketatanegaraan suatu negara yang bersifat fundamental (Soemantri, 2006:59).

Apabila dijewntahkan dalam sebuah undangundang, maka substansi pemenuhan hak konstitusional warga negara harus nampak jelas. Menganalisis contoh undang-undang yang dikemukakan pada sub bab sebelumnya, secara substansial UU Penyiaran tidak pernah terlepas dari beragam interest, baik itu oleh pengusaha pers, Pemerintah maupun DPR. Persoalan otoritas pengaturan penyiaran yang tetap berada ditangan pemerintah, dalam hal ini memberikan kekuasaan kepada pemerintah untuk mengatur, mengintervensi dan mengontrol penyiaran, sedangkan, dalam kewenangan pemberian izin frekwensi, KPI hanya sebatas pengusul. Jika dibandingkan dengan negara-negara otoriter seperti Korea Utara, Myanmar, dan Kuba, badan pengatur penyiaran adalah pemerintah, sementara di negara-negara demokrasi seperti Korea Selatan, Afrika Selatan, Amerika Serikat badan pengatur penyiaran adalah badan publik independen ( $a n$ independent regulatory body) (Laksono dan Subardjo, 2006:118)

Oleh sebab itu, UU No. 32 Tahun 2002 tentang Penyiaran dipertanyakan perihal jaminan 
serta terpenuhinya tuntutan kebutuhan akan hak kemerdekaan informasi yang demokratis, dan diindikasi bertentangan dengan Pasal 28F UUD NRI Tahun 1945 yang menyatakan setiap orang berhak untuk berkomunikasi dan memperoleh informasi untuk mengembangkan pribadi dan lingkungan sosialnya, serta berhak untuk mencari, memperoleh, memiliki, menyimpan, mengolah, dan menyampaikan informasi dengan menggunakan segala jenis saluran yang tersedia. Ketentuan terebut mengandung pengertian bahwa setiap warga negara berhak memperoleh jaminan konstitusi (constitutional guarantee).

Hal serupa juga terdapat dalam persoalan Pilkada apakah termasuk dalam bagian dari pemilihan umum yang atau tidak, seperti tertuang pada Pasal 18 ayat 4 dengan Pasal 22EUUD NRI Tahun 1945 yang debatebel. Pembentukan UU No. 22 Tahun 2014 sebagaimana telah diubah dengan UU No. 1 Tahun 2015 dan diubah menjadi UU No. 8 Tahun 2015 tentang Pemilihan Gubernur, Bupati, dan Walikota, sebagai perintah atributif dalam Pasal 18 ayat (4) UUD NRI Tahun 1945 yang menyatakan "Gubemur, Bupati, dan Walikota masing-masing sebagai kepala pemerintah daerah provinsi, kabupaten, dan kota dipilih secara demokratis". Adapun politik pemilihan Gubernur, Bupati, dan Walikota dalam hal memaknai frase "dipilih secara demokratis" selalu mengalami perubahan sesuai dengan perkembangan zaman. Hal inilah yang kemudian menjadi dasar bahwa terdapat perubahan metode pemilihan Gubernur, Bupati, dan Walikota yang dapat dilaksanakan baik itu secara langsung maupun tidak langsung. Tidak memiliki kejelasan dasar metode pemilihan Gubernur, Bupati, dan Walikota baik itu secara langsung maupun tidak langsung dalam artian "dipilih secara demokratis" haruslah jelas. Menentukan kebijakan yang akan diterapkan menjadi penting untuk dipertanyakan konstitusionalitasnya karena rentan sekali terjadi inkonstitusional dan melanggar hak konstitusional. PERPU No. 1 Tahun 2014 yang Kemudian ditetapkan menjadi UU No. 1 Tahun 2015 mengemukakan untuk menjamin Pemilihan Gubernur, Bupati, dan Walikota dilaksanakan secara demokratis sebagaimana diamanatkan dalam Pasal 18 ayat (4) UndangUndang Dasar Negara Republik Indonesia Tahun 1945 maka kedaulatan rakyat serta demokrasi dari rakyat, oleh rakyat, dan untuk rakyat wajib dihormati sebagai syarat utama pelaksanaan
Pemilihan Gubernur, Bupati, dan Walikota. Kedaulatan rakyat dan demokrasi tersebut perlu ditegaskan dengan pelaksanaan Pemilihan Gubernur, Bupati, dan Walikota secara langsung oleh rakyat, dengan melakukan beberapa perbaikan mendasar atas berbagai permasalahan pemilihan langsung yang selama ini telah dilaksanakan. Namun, pembentukan UndangUndang Nomor 22 Tahun 2014 tentang Pemilihan Gubernur, Bupati, dan Walikota yang mengatur mekanisme pemilihan kepala daerah secara tidak langsung melalui Dewan Perwakilan Rakyat Daerah telah mendapatkan penolakan yang luas oleh rakyat dan proses pengambilan keputusannya tidak mencerminkan prinsip demokrasi. Keputusan tidak mencerminkan prinsip demokrasi jelas akan melanggar hak konstitusional warga negara, Pilkada tidak langsung bertentangan dengan hak konstitusional warga karena hak memilih terletak di individu.

Hak memberikan suara atau memilih merupakan hak dasar setiap individu atau warga negara yang harus dijamin pemenuhannya oleh Negara. Ketentuan mengenai ini, diatur dalam Pasal 1 ayat (2), Pasal 2 ayat (1), Pasal 6A (1), Pasal 19 ayat (1) dan Pasal 22C (1) UUD 1945. Perumusan sejumlah pasal tersebut sangat jelas bahwa negara harus memenuhi segala bentuk hak asasi setiap warga negaranya, dalam hal ini khususnya berkaitan dengan hak pilih setiap warga negara dalam Pilkada di Indonesia. Sebagaimana halnya dengan UU No. 42 tahun 2008 tentang Pilpres, penciptaan suatu norma hukum yang tidak jelas indikatornya rentan melanggar hak asasi manusia serta bertentangan dengan konstitusi dan norma-norma hukum lainnya seperti dalam pembentukan UU No. 42 tahun 2008 tentang Pilpres ini. Oleh karena itu, kejelasan dasar pemberlakuan ambang batas formal dalam perolehan suara dalam penyelenggaraan pemilihan umum dan parameter hukum dalam menentukan persentase yang akan diterapkan menjadi penting untuk dipertanyakan konstitusionalitasnya karena rentan sekali terjadi inkonstitusional dan melanggar hak konstitusional. Pengaturan ambang batas formal memberikan pengaruh signifikan dalam upaya penciptaan sistem pemilihan umum yang memenuhi nilai-nilai demokrasi bangsa Indonesia.

Urgensi konstitusionalitas dari berbagai kasus yang dijelaskan di atas tertuang di dalam teori pembentukan undang-undangan ada 5 faktor yang harus diperhatikan, yaitu: 
a. Faktor wewenang, apakah badan yang sedang menyusun undang-undang adalah badan yang diberi wewenang secara konstitusional;

b. Faktor substansi, artinya apakah substansi yang akan dimasukkan dalam undang-undang, sudah sewajarnya dimasukkan dalam undangundang;

c. Faktor heuritik, dalam arti apakah substansi undang-undang telah mengakomodasikan faktor-faktor sosial, budaya dan psikologi masyarakat;

d. Faktor konstitusional, apakah isi undangundang telah mempertimbangkan peraturanperaturan yang berlaku dalam satu tatanan hukum terhadap UUD;

e. Faktor prosedural, yang artinya apakah badan negara yang berwenang telah memperhatikan tata cara pembentukan hukum (Soewoto, 1990:34).

Faktor tersebut berguna untuk mengurangi kemungkinan adanya hukum atau dalam hal ini undang-undang yang tidak adil. Dengan melalui tata cara pembuatan hukum yang teratur baik maka ketidakadilan dapat dikurangi. Ketentuanketentuan yang terdapat di dalam konstitusi memiliki makna penting dan konsekuensi besar untuk dilaksanakan dengan sungguh-sungguh dan tanpa ada pengecualian, baik melaui beragam kebijakan pembentukan undang-undang maupun produk peraturan perundang-undangan di bawahnya. Dalam kaitannya dengan dampak terhadap konstitusionalitas dan perlindungan terhadap hak konstitusional, maka dapat ditarik kesimpulan bahwa pembentukan undang-undang yang sangat syarat akan resistensi politik antara DPR dan Presiden, akan menimbulkan adanya penafsiran tertentu dalam norma konstitusi yang berbeda dari original intens norma konstitusi tersebut hingga berakibat terlanggarnya hak konstitusional yang dijamin oleh konstitusi.

\section{Urgensi pengeluaran fatwa hukum oleh Mahkamah Konstitusi}

Mahkamah Konstitusi dalam mengeluarkan fatwa atau pendapat hukum atas penafsiran terhadap konstitusi, bisa dilihat melalui Putusan No. 108/PUU-XI/2013 yang menyatakan amar putusan bahwa Mahkamah Konstitusi tidak berwenang dalam melakukan penafsiran UUD NRI Tahun 1945. Tentu pengucapan putusan tersebut bertentangan dengan tugas dan fungsi
Mahkamah Konstitusi sendiri dalam menafsirkan UUD NRI Tahun 1945. Sementara, pemohonan penafsiran yang dimohonkan dalam putusan tersebut, dinilai oleh Mahkamah Konstitusi sebagai permintaan "fatwa" sehingga Mahkamah Konstitusi menyebutkan bahwa permohonan pemohon untuk menafsirkan konstitusi tidak menjadi kewenangan Mahkamah Konstitusi.

Sebenarnya untuk dapat mengetahui konstitusionalitas UU tidak dapat dilaksanakan tanpa ada kewenangan untuk menginterpretasikan pasal-pasal dalam konstitusi yang memiliki kekuatan hukum. Prinsip dasar dari perwujudan keadilan dalam konstitusi tidak dapat tercapai apabila masing-masing cabang diberikan kekuasaan untuk menginterpretasikan konstitusi sesuai dengan interpretasinya sendiri-sendiri. Pernyataan ini didasarkan pada pengalaman praktis ketatanegaraan pada masa Pemerintahan Orde Baru, UUD 1945 ditafsirkan menurut kehendak masing-masing cabang kekuasaan negara, sehingga tidak jarang terjadi pertentangan satu sama lain yang pada akhhirnya mengakibatkan tidak stabilnya pemerintahan (Latif, 2007:324).

Tidak stabilnya pemerintahan dalam pembentukan undang-undang disebabkan karena interpretasi terhadap konstitusi yang berbeda oleh DPR dan Presiden, sehingga menimbulkan perdebatan sangat pelik dalam pembahasan RUU di DPR yang juga berimplikasi terhadap respon masyarakat luas, bahkan sebelum RUU itu diundangkan ancaman judicial review ke Mahkamah Konstitusi sudah dilayangkan. Fenomena seperti ini semakin menguatkan kepada anggapan bahwa pembentukan undang-undang adalah manifestasi kepentingan politik semata yang mengabaikan konstitusi dan hak konstitusional masyarakat. Jika terjadi secara terus menerus, maka akan mengacaukan kehidupan bernegara.

Oleh karena itu di dalam ajaran pembagian kekuasaan mekanisme checks and balances merupakan upaya untuk menciptakan relasi konstitusional guna mencegah penyalahgunaan kekuasaan di antara cabang-cabang kekuasaan negara, termasuk untuk membangun keseimbangan hubungan dalam praktek penyelenggaraan negara antara pembentuk undang-undang dalam hal ini oleh DPR yang dilakukan bersama Presiden serta DPD dengan lembaga negara yang diberikan kewenangan dalam mengawal konstitusi yakni Mahkamah 
Konstitusi. Maka dari itu, titik berat pemisahan kekuasaan terletak pada kejelasan posisi tiap-tiap cabang kekuasaan negara dalam menjalankan fungsi-fungsi konstitusionalnya. Sementara, titik tekan mekanisme cheks and balances ialah pada upaya membangun harmoni dan perimbangan kekuasaan untuk menciptakan situasi yang saling kontrol antar-cabang kekuasaan negara. Sistem ini sangat mencegah terjadinya over lapping sebagaimana dalam kekuasaan membentuk undang-undang yang sangat riskan dengan pengaruh politik praktis sehingga mengabaikan konstitusi yang didalamnya mengatur hak konstitusional warga negara. Oleh karena itu hubungan harmoni dan perimbangan kekuasaan agar terhindar dari hal-hal yang tidak konstitusional dan mengakibatkan dilanggarnya hak konstitusional maka urgen Mahkamah Konstitusi dalam memberikan nasehat hukum terhadap penafsiran norma konstitusi yang dijadikan titik permasalahan dalam pengambilan kebijakan pembetukan undang-undang. Hal ini, tidak lain adalah agar dapat terlindunginya hak konstitusional secara preventif melalui penafsiran oleh Mahkamah Konstitusi dalam bentuk fatwa atau pendapat hukum.

Sebenarnya undang-undang juga merupakan bentuk penafsiran terhadap ketentuan dalam konstitusi oleh pembentuk undang-undang, arti interpretasi dalam hal ini sebagai sarana untuk mengatur daya kelenturan konstitusi (melihat norma materi-muatan konstitusi yang abstrak) yang dapat terjadi pada hukum (undang-undang) yang dibuat oleh pembentuk undang-undang untuk tujuan politik. Namun demikian, penafsiran tersebut dapat saja terjadi kekeliruan dan dianggap bertentangan dengan UUD NRI Tahun 1945 oleh warga negara, lembaga negara lain, badan hukum tertentu, atau kesatuan masyarakat hukum adat, karena melanggar hak dan kewenangan konstitusional mereka. Terhadap perbedaan tafsir tersebut, Mahkamah Konstitusi-lah yang memberikan putusan akhir dalam penafsiran. Fungsi inilah yang disebut sebagai the final interpreter of the constitution. Mahkamah Konstitusi membawa semangat sebagai penjamin terpenuhinya hak konstitusional warga negara, serta menjadi penyeimbang antar pokok-pokok kekuasaan negara sesuai dengan prinsip chek and balances (Hadjar, 2003:3). Dengan latar belakang tersebut, MK sebagai lembaga negara yang hadir setelah perubahan ketiga UUD 1945 disahkan, mempunyai gelar sebagai "The guardian of the constitution" (pengawal konstitusi) terkait dengan empat kewewenangan dan satu kewajiban yang dimilikinya.

Hal tersebut tentu membawa konsekuensi berikutnya, MK berfungsi sebagai "The sole interpreter of the constitution" (penafsir konstitusi). Lalu karena konstitusi merupakan hukum tertinggi yang mengatur penyelenggaraan negara, berdasarkan prinsip demokrasi, maka MK juga berfungsi sebagai "The guardian of the democracy" (pengawal demokrasi), "The protector of the citizen's constitutional rights" (pelindung hak konstitusional warga negara) serta "The protector of human rights" (pelindung hak asasi manusia) (Asshiddiqie, 2008:547-548). Pada titik inilah posisi Mahmakah Konstitusi sangat penting dalam dinamika ketatanegaraan Indonesia.

Fatwa hukum Mahkamah Konsitusi sebagai implikasi teoritis kewenangan menguji konstitusionalitas undang-undang terhadap UUD NRI Tahun 1945 oleh Mahkamah Konstitusi setidaknya didasarkan pada komitmen untuk mencegah tindakan-tindakan peyelenggaraan negara yang tidak sesuai dengan konstitusi sebagai hukum dasar tertinggi negara. Selain itu pengujian konstitusional rancangan undang-undang melalui penafsiran terhadap konstitusi merupakan kontrol antarlembaga negara (cheks and balances) untuk terwujudnya cita negara hukum yang demokratis yang mengedepankan supremasi konstitusi.

Dengan demikian, konstitusi adalah sebuah kontrak politik yang mengikat antara rakyat dan negara. Kedaulatan ada di tangan rakyat dan kedaulatan rakyat tersebut diorganisasikan ke dalam lembaga-lembaga negara. Akan tetapi, lembaga-lembaga negara pada tahap melaksanakan kedaulatan rakyat, bukan tidak mungkin menyimpang dari kesepakatankesepakatan seperti yang telah digariskan dalam konstitusi. Penyimpangan itu biasanya dapat dilihat dari produk hukum yang diciptakannya. Jadi, fungsi primer interpretasi konstitusi dalam pengujian rancangan undang-undang adalah untuk menilai apakah kesepakatan-kesepakatan yang dituangkan dalam hukum tertinggi itu dijalankan secara baik dan benar oleh masing-masing lembaga negara.

Oleh karena itu, sangatlah tepat dan penting bagi pembentuk undang-undang pada waktu proses 
pembahasan antara DPR dan Presiden untuk mendapatkan persetujuan bersama, agar mengajukan permintaan fatwa atau pertimbangan hukum kepada Mahkamah Konstitusi terhadap penafsiran norma tertentu dalam konstitusi dan/ atau terhadap suatu norma dalam RUU yang patut dipertanyakan konstitusionalitasnya. Disebabkan hal tersebut menimbulkan adanya perbedaan pendapat terhadap penafsiran norma konstitusi antara DPR dan Pemerintah. Upaya ini tidak lain untuk langkah preventif dalam menjaga konstitusionalitas suatu undang-undang yang akan dibentuk, dan hal ini tentu sebagai perlindungan hak konstitusional warga negara.

\section{Kesimpulan}

1. Pembentukan undang-undang secara signifikan dapat dikatakan belum baik, hal itu tergambar dari banyaknya permohonan uji materiil terhadap produk legislasi dan undang-undang yang dibatalkan oleh Mahkamah konstitusi.

\section{Daftar Rujukan}

Buku:

Asshiddiqie, Jimly. 2014. Konstitusi dan Konstitusionalisme Indonesia, Jakarta: Sinar Grafika. 2008. Menuju Negara Hukum

Demokratis, Jakarta: Sekretariat Jenderal Mahkamah Konstitusi. 2005. Model-Model Pengujian Konstitusional di Berbagai Negara, Jakarta: Konpres.

Dahlan Thab, et.al., 2001. Teori dan Hukum Konstitusi, Jakarta: RajaGrafindo Persada.

Hadjar, A. Fickar, dik., 2003. Pokok-pokok Pikiran dan Rancangan Undangundang Mahkamah Konstitusi, Jakarta: KHRN dan Kemitraan.

Hamid, Zulkifli. 2000. Pengantar Perbandingan antar Hukum Tata Negara, Jakrta: RajaGrafindo Persada.

Ibrahim, Johnny. 2012. Teori \& Metodologi Penelitian Hukum Normatif, Cetakan ke-6, Jakarta: Bayumedia Publishing.

Laksono, Fadjar dan Subardjo. 2006. Kontroversi Undang-Undang Tanpa Pengesahan Presiden, Yogyakarta: UII Press.

Latif, Abdul. 2007. Mahkamah Konstitusi dalam Upaya Mewujudkan Negara Hukum
Terindikasi bahwa salah satu penyebab/ problemnya karena norma materi-muatan konstitusi yang abstrak, yang membutuhkan penafsiran terhadap penerapannya dalam ketentuan undang-undang.

2. Norma materi-muatan konstitusi yang bersifat abstrak, memimbulkan perbedaan dalam penafsiran dan berdampak terhadap konstitusionalitas undang-undang yang akan dibentuk dan terlanggarnya hak konstitusional warga negara.

3. Urgensi Mahkamah Konstitusi dalam mengeluarkan fatwa hukum atas penafsiran norma konstitusi dalam pembentukan undangundang karena adanya resistensi politik antara DPR dan Presiden disebabkan perbedaan penafsiran dalam norma konstitusi, fatwa hukum yang dikeluarkan Mahkamah Konstitusi bertujuan agar terwujudnya cita negara hukum yang demokratis yang mengedepankan supremasi konstitusi.

Demokrasi, Yogyakarta: Kreasi Total Media.

Marzuki, Peter Mahmud. 2010. Penelitian Hukum, Cetakan ke-6, Jakarta: Kencana.

Moh. Mahfud MD, Dkk., 2010. Constitutional Question Alternatif Baru Pencarian Keadilan Konsttusional, Malang: UB Press.

Palguna, I Dewa Gede. 2013. Pengaduan Konstitusional (Upaya Hukum terhadap Pelanggaran Hak-Hak Konstitusional Warga Negara), Jakarta: Sinar Grafika.

Soemantri, Sri. 1984. Pengantar Perbandingan Antar Hukum Tata Negara, Jakarta: CV Rajawali,. 2006. Prosedur dan Sistem Perubahan Konstitusi, Bandung: PT Alumni.

Wheare, K.C. 1975. Modern Constitution, New York: Oxford University Press,.

Jurnal:

Rajab, Achmadudin, Tinjauan Hukum Eksistensi dari UU No. 8 TAHUN 2015 setelah 25 kali Pengujian Undang-Undang di Mahkamah Konstitusi Pada Tahun 
2015, Jurnal Hukum dan Pembangunan Tahun ke-47 No.3 Juli-September 2016.

Sodikin, Pemilu Serentak (Pemilu Legislatif dengan Pemilu Presiden dan Wakil Presiden) dan Penguatan Sistem Presidensial, Jurnal RechtsVinding, Volume 3 Nomor 1, April 2014.

Soewoto, Metode Interpretasi Hukum Terhadap Konstitusi, Jurnal Yuridika Fakultas Hukum Universitas Airlangga No. 1 Tahun V, Januari-Februari 1990, hlm. 34.

\section{Peraturan Perundang-undangan:}

Undang-Undang Dasar Negara Republik Indonesia Tahun 1945.

UU No. 32 Tahun 2002 tentang Penyiaran.

UU No. 42 Tahun 2008 tentang Pemilihan Umum Presiden dan Wakil Presiden

UU No. 22 Tahun 2014 Tentang Pemilihan Gubernur, Bupati Dan Walikota.

Putusan Mahkamah Konstitusi No. 3/PUU-VII/ 2009.

Putusan Mahkamah Konstitusi Nomor 97/PUU$\mathrm{XI} / 2013$.

Putusan Mahkamah Konstitusi Nomor 108/PUU$\mathrm{XI} / 2013$
Artikel dan Internet:

Devi Aryani dalam artikel "Pentingnya Pemahaman Implementasi UUD 1945 tentang Peemilihan Uumum dalam Undang-Undang No. 42 Tahun 2008 tentang Pilpres" http://deppoyaryani. blogspot.co.uk/2014/05/pentingnyapemahaman-implementasi-uud.html, diakses pada tanggal 18 Juli 2017.

http://www.mahkamahkonstitusi.go.id/ index.php?page=web.RekapPUU\&menu=5, diakses pada tanggal 10 Mei 2017.

http://news.detik.com/berita/2808114/hari-ini-uupilkada-langsung-disahkan-begini kisahperjalanannya, diakses pada tanggal 12 Juli 2017.

http://www.mahkamahkonstitusi.go.id/ index.php?page=web.RekapPUU\&menu=5, diakses pada tanggal 10 Mei 2017.

Rinaldo, http://news.liputan6.com/read/2110251/ dpr-akhirnya-memilih-pilkada-melalui-dprd, diakses pada tanggal 12 Juli 2017. 